\title{
Double exposure to capitalist expansion and climatic change: a study of vulnerability on the Ghanaian coastal commodity frontier
}

\author{
Callum Nolan $^{1}$ Izabela Delabre $^{2}$, Filippo Menga $^{3}$ and Michael K. Goodman ${ }^{1}$
}

\begin{abstract}
Jason Moore's theory of the commodity frontier serves as a useful framework for demonstrating the social-ecological upheaval that occurs in the "frontier" spaces to which capitalism must expand in search of uncommodified, cheap nature. Work to date however has failed to consider how the impacts of frontier expansion interact with climate change despite the two phenomena being closely linked in both causes and effects, and largely impacting most severely upon rural communities in the Global South. We seek to address this gap with a focus on the coastal commodity frontier: social-ecological systems within which marine and terrestrial frontier expansion can occur concurrently, while being impacted by climatic change. The research was conducted using an ethnographic, casestudy approach, centred on an eight-month research visit to Aboadze, a small-scale marine fishing community in the Western Region of Ghana. This community is subject to terrestrial frontier expansion in the form of a thermal power station, marine frontier expansion in the form of industrial overfishing, and is also exposed to the impacts of climate change. We find, through a double exposure vulnerability framework, that frontier expansion and climatic change interact to exacerbate food, water, and livelihood insecurities in the case-study community, while simultaneously reducing the community's capacity to adapt to its changing environment and perpetuating harmful global changes through feedback exposures. This research makes an important conceptual contribution by galvanizing a conversation between two thus far disparate fields and invites further research to provide more nuanced analyses of the intersectional vulnerabilities impacting coastal communities.
\end{abstract}

Key Words: climate vulnerability; coastal commodity frontier; double exposure; small-scale marine fishing

\section{INTRODUCTION}

The concept of the commodity frontier originates from the work of Jason Moore (2000:209) and was developed as an alternative to existing world-system analyses of capitalist expansion that failed to acknowledge capitalism's "structural tendency towards environmental degradation." The notion of a commodity frontier refers to those previously uncommodified spaces into which capital must expand and commodify nature to perpetuate itself, following the degradation of previous landscapes. The capitalist metabolism requires "cheap" nature to sustain itself, in particular food, labor, energy, and raw materials, and has thus historically expanded to regions relatively untouched by capital to consume these resources (Moore 2010). The result is the creation of a distinct socio-spatial configuration characterized by conflict, enclosure, environmental degradation, the upheaval of existing hegemonies, and changing patterns of access and control to natural resources. In these spaces, Indigenous communities often find themselves subject to violence, in the broad sense of increased vulnerability, at the hands of corporate and state actors (Moore 2018). In particular, through research such as Gilbert's (2018) on rubber and oil frontiers, Moore's (2010) work on sugar frontiers and Saguin's (2016) work on aquaculture frontiers, scholars have depicted both the historical and contemporary social-ecological upheavals that occur as a result of the process of capitalist expansion. As a result, we are beginning to develop a better understanding of the violence that often impacts rural and natural resource-dependent communities situated on the frontier.

We argue that revealing how multiple social-ecological changes interact and have an impact on local people can further develop our understanding of commodity frontiers. One stressor that is often omitted from previous frontier research is climate change, despite already having deleterious impacts on rural communities globally, with many of these communities also constituting sites of contemporary commodity frontier expansion. As a result, climate change is compounding existing, and giving rise to new, intensified inequalities and vulnerabilities for increasingly marginalized communities across a series of commodity frontiers on a global scale.

Our argument thus builds on existing work on commodity frontiers by exploring climate vulnerability in the coastal commodity frontier, depicting how capitalist expansion and one of its many externalities, climate change, interact with one another and the precarity this creates. In addition, we look to expand Moore's and others' research by extending the geographical consideration of the commodity frontier, which had previously focused primarily on land-based resources, to understand the impacts of capitalist expansion on coastal regions and the oceans upon which they often rely. Coastal communities are some of the most vulnerable to climate change, particularly those reliant on capture fisheries as their primary source of nutrition and economic income (IPCC 2019). Rising sea levels and coastal erosion are destroying homes and livelihood assets while, simultaneously, oceans are becoming warmer, more acidic, and less oxygenated, fundamentally denigrating marine ecosystems and their productivity.

Coastal regions also find themselves targets for capitalist expansion, be it through the plundering of fish by large international fleets and/or the appropriation of vast swathes of coastal lands for aquaculture, infrastructure, or tourism, or in many cases, a combination of these factors. To further our argument, we draw upon the case study of Aboadze, a small-scale 
marine fishing (SSMF) community in the Western Region of Ghana. Within one generation, this small town has seen massive upheaval at the nexus of climatic change, overfishing by Western European, Russian, and Chinese distant water fleets (Atta-Mills et al. 2004, EJF 2018) and the construction and expansion of a thermal power station, which has been developed and operated largely by private and often international financiers including the Abu Dhabi based energy company TAQA, METKA energy of Greece, and General Electric.

Analytically, we engage with the meta-concept of "double exposure" (O'Brien and Leichenko 2000). Double exposure seeks to identify various ways in which climate change interacts with other global changes such as capitalism and neoliberalism, both directly and through feedbacks, creating accentuated "winners" and "losers" in relation to environmental changes. It is increasingly acknowledged (e.g., Freduah et al. 2019) that particularly for those most vulnerable, climate change occurs alongside other stressors as well as in combination with other forms of political, social, economic, and geographic marginalization. Therefore, to develop a holistic picture of onthe-ground vulnerability in an era of climate change and continued capital and market-expansionism, researchers must look at the confluence of stressors facing communities and how these stressors interact with one another to curtail access to the vital resources upon which they rely.

\section{COASTAL COMMODITY FRONTIERS: EXPANDING ON A CONCEPT}

The commodity frontier mode of capitalist expansion is a concept first developed by Jason Moore (2000) to describe the process through which capitalism perpetuates itself through constantly seeking and acquiring "cheap" food, labor, energy, and raw materials. Capitalism's expansionary nature means that it will seek yet-to-be commodified spaces, exploit them until the point of ecological decimation or economic unviability (or other factors, such as continued social unrest) and then repeat. Although there is a burgeoning body of literature that explores marine commodity frontiers (e.g., Ertór and Ortega-Cerda 2018), extant work on the subject has primarily focused on land-based resources such as palm oil, sugar, and timber (Marley 2016). Such a landcentric focus obscures the extent to which coastal resources, which will be understood here as the resources on coastal lands, including the lands themselves, and those in the sea, are being subsumed within waves of capital accumulation. Growing world appetites for seafood, and the associated industrialisation of the global fishing industry have decimated stocks, with the FAO (2020) estimating that $34 \%$ of oceans are currently overfished. Additionally, coastal areas worldwide are transforming, often becoming sites for infrastructure or developed for tourism (Bavinck et al. 2017). We contend that although demonstrating patterns similar to land-based frontier spaces, the coastal frontier is unique as a space in which separate manifestations of capital accumulation can converge and dialectically produce unique forms of violence upon, and vulnerability within, local communities.

There remains significant scope to further unpack and explore the concept of coastal frontiers and to evince a better understanding of where their processes and impacts mirror land- based frontier expansion and where they differ. Existing work to date has shown that there are numerous shared characteristics between terrestrial and marine frontier spaces. Fabinyi et al. (2018) highlighted that like on land, coastal frontiers are both discursive and material spaces in which rapid transformations occur. They demonstrate this through a scaled political ecology approach in which they look at control and access to resources, with class and ethnicity being among some of the key determinants of ability to access fish and fish resources. In recent years, we have seen an increasing focus by social scientists on the concept of ocean, blue, or coastal grabbing. Although not explicitly invoking the concept of commodity frontiers, this is an expansion of the work on land grabbing that has documented how powerful actors have dispossessed rural communities through a variety of mechanisms and as an often integral part of commodity frontier expansion. Ocean grabbing is defined as "dispossession or appropriation of use, control or access to ocean space or resources from prior resource users, rights holders or inhabitants" (Bennett et al. 2015:62). Benjaminsen and Bryceson's (2012) study of "blue grabbing" in Tanzania in the name of marine conservation paints a vivid picture of the contradictions that political ecologists often highlight. They argue that marine conservation, an ostensibly normative concept designed to protect the ocean and its inhabitants, has ultimately led to the displacement of local communities and their exclusion from access to benefits. Barbesgaard (2018) applied the lens of ocean grabbing to the "blue growth" agenda, in which neoliberal discourses of win-win and market logics are offered as solutions to tackle declining fish stocks and ocean health. Overall, Barbesgaard argued that blue growth imposes disproportionate costs upon small-scale users while allowing continued intensive, large-scale fishing that plunders the seas.

Existing work on capital accumulation in coastal and maritime regions suggests that coastal frontiers share many characteristics with those on land (e.g., Campling 2012, Fabinyi 2018). Within these regions are patterns of dispossession, with powerful actors ultimately obtaining control over valuable resources. Here, coastal regions often find themselves trapped between two concurrent instances of commodity frontier expansion, i.e., overfishing at sea and coastal development on land, compounding the vulnerability that arises from either and/or both. Although capitalist expansion continues at sea, witnessed primarily through intensive fishing by large, private industrial fleets decimating the fish stocks upon which SSMF heavily rely, many communities are seeing coastal lands claimed and used by the state, private actors, and even conservation organizations, with further negative consequences. Largely speaking, when academic research discusses frontier spaces (and particularly terrestrial ones) the focus is on one commodity. Coastal regions however are socioeconomic systems in which commodity frontiers affecting terrestrial and marine spaces meet. Thus, we make a theoretical contribution through our examination of the interactions between these converging frontiers and climatic change, a phenomenon that poses a similarly existential threat to coastal communities. Fabinyi et al. (2018:4) mention that their case study site (the Palawan province of the Philippines) is a region with "multiple frontier processes unfolding," and although their research certainly provides a building block to understanding the interactions between 
multiple frontier processes, more work is needed to understand and theorize these dynamics.

\section{THE "DOUBLE EXPOSURE" FRAMEWORK FOR ANALYZING VULNERABILITY IN COASTAL COMMODITY FRONTIERS}

Numerous authors have highlighted the importance of recognizing the interactions of the various environmental, economic, and social stressors that impact and shape vulnerability (e.g., Shackleton and Shackleton 2012, Otto et al. 2017). To analyze the vulnerability occurring at the nexus of capitalist expansion and climate change, we draw upon the double exposure framework, originally developed by O'Brien and Leichenko (2000; see also Leichenko and O'Brien 2002), who argued that exploring global economic and environmental stressors in abstraction from one another allows "critical linkages, feedbacks and synergies" between stressors to go unnoticed (Leichenko et al. 2010:966). Although globalization was the economic measure originally used in examining double exposures, research has since used a broader set of non-climatic phenomena as stressors, such as the global financial crisis (Leichenko et al. 2010) and extractive industries (Bebbington et al. 2015).

One of the central concepts to the double exposure framework is the fact that there are winners and losers produced by global climate and economic change, mirroring the broader tradition of political ecology as a normative approach. Those who have benefited most from both capitalist expansion and climate change have largely avoided the worst of their negative ramifications, which in both cases are felt most by those who have contributed least and are most often located in the developing world. The latter point is of particular interest when exploring vulnerability because the geographical overlap of these global phenomena implies that despite their impacts being studied separately, they are occurring simultaneously, with implications for how we analyze vulnerability: "[W]inners are considered those countries, regions or social groups that are likely to benefit from the ongoing processes of climate change or globalization, while losers are those that are disadvantaged by the processes and likely to experience negative consequences" (O'Brien and Leichenko 2000:222). Within those "units" that are doubly exposed, there can arise "double winners" and "double losers," which can provide a useful heuristic for identifying the most vulnerable. This approach also highlights the fact that it is often those worst impacted by climate change who are also worst impacted by other processes of global economic change, bringing to the fore issues of justice and inequality (Meerow 2017).

Leichenko and O'Brien (2008) fleshed out the interactions between climatic and economic changes, dividing them into three categories: outcome double exposures, context double exposures, and feedback double exposures. Outcome refers to when a particular facet of a unit's existence is subject to the impact of both stressors simultaneously, normally converging around issues such as food and water security and the ability to maintain livelihood activities. Context double exposure describes when one global force creates social, economic, political, biophysical, and/ or cultural changes in the contextual environment of the units in question. In turn, this can alter the extent and ways in which the units are able to respond to stressors. Finally, feedback double exposures occur when one stressor can initiate adaptive or maladaptive actions that exacerbate the original global processes.

In paying such close attention to the specific interactions between global processes, the double exposure framework makes a fruitful addition to our understanding of whether the effects of multiple and interacting stressors are additive or synergistic. Stressors are seen to be synergistic when "their combined effect is larger than predicted from the sizes of the responses to each stressor alone" (Vinebrook et al. 2004:452). Double exposure in marine systems has been found to be commonly synergistic in quantitative natural science research (e.g., Sih et al. 2004, Crain et al. 2008), however little social science research has addressed this issue. The double exposure framework as devised by O'Brien and Leichenko provides a suitable framework with associated language and methodologies within which to explore these synergies, in addition to how they cross and work across different scales.

Literature on the commodity frontier provides historical and empirical accounts that map both the processes and the socialecological and economic ramifications of capitalism's frontier mode of expansion, depicting the lived experiences of vulnerability within frontiers (Fabinyi et al. 2018, Nolan et al. 2019). However, a more nuanced understanding of vulnerability on the commodity frontier is needed, by considering how the externalities of capitalist expansion interact with those of climatic change. Using double exposure as an analytical lens applied to coastal fishing communities is particularly pertinent when focusing on regions that are both highly vulnerable to climate change and have suffered marginalization and poverty at the hands of global economic change (Lennox 2015).

The most imminent threat to most fishing communities is the rapacious overfishing occurring in almost all of the world's oceans, rapidly reducing the access of small-scale fishers to the fish that are integral to their livelihoods (Crona et al. 2015). Although not explicitly invoking the double exposure framework, recent work by Sumaila and Tai (2019) has begun to conceptually explore novel links between overfishing (which could be considered a global process in and of itself, or if not, certainly a by-product of capitalist expansion) and climate change. Sumaila and Tai argued that ending overfishing serves as a means of climate mitigation because it would support increased ocean biomass and therefore the resilience of the ocean. This line of thinking lends itself to analysis through the lens of double exposure and forms a central question of our research: how has frontier expansion altered the contextual environments of the case study community, and what are the impacts on the community's climate sensitivity and adaptive capacity? The interactions between climatic and economic stressors, and the dynamic vulnerabilities that are produced as a result, are poorly understood (Freduah et al. 2017). The application of the double exposure framework for better understanding the compounded vulnerabilities on the commodity frontier therefore makes a timely and novel contribution.

\section{CLIMATE CHANGE AND FISHING COMMUNITIES IN WEST AFRICA}

Fishing communities in economically poorer regions of the world such as sub-Saharan Africa and South-East Asia are considered 
some of the most vulnerable to climate change (Allison et al. 2009). Marine spaces are undergoing fundamental changes as a result of anthropogenically induced temperature increase. Recent research has found that $90 \%$ of the heat gained by the planet between 1971 and 2010 was absorbed by the ocean (Zanna et al. 2019), with catastrophic impacts upon its many ecosystems. This issue is becoming increasingly problematic, with records for ocean warming being broken year upon year since the turn of the century (IPCC 2019). These rising temperatures cause issues such as increased oceanic acidity, sea-level rise, reduced oxygen, and increased salinity (IPCC 2019), which fundamentally alter ecosystems and weather conditions, as well as the lives of millions of people globally and, in particular, coastal communities reliant on the ocean's natural resources.

There are numerous ways in which climate-induced changes affect fish and those who derive a livelihood from their capture. The impacts upon fish stocks can be broadly dichotomized into two categories, stock productivity and stock distribution (Gaines et al. 2018). Warmer ocean temperatures have been linked to fish stocks having smaller maximum body sizes, and those with smaller body sizes in warmer climates are prone to higher natural mortality rates, with cascading impacts on population dynamics and productivity (Sumaila et al. 2011), as well as the economic and nutritional value of catch. Changes in stock distribution (i.e., where fish are found, and who catches them) occur because fish have been observed traveling to higher latitude and deeper waters in search of their optimal environmental preferences. For many, these changes will mean fishers spending longer at sea and traveling farther to catch fish, practices made more dangerous by the intensified sea storms associated with rising temperatures. Sea-level rise and worsening storms also have land-based impacts for fishing communities, which are often situated in low-lying coastal regions and as such are at risk of damage to property and infrastructure, displacement, and forced migration. Furthermore, climate change affects the health conditions of fishing communities because thunderstorms and warmer temperatures are linked with increasing instances of malaria, respiratory diseases, and skin diseases (Daw et al. 2009), ultimately having an impact on the ability of fishers and processors to operate effectively and safely.

Existing research on West African fisheries under climate change suggests that the region's fish stocks and communities will be heavily impacted by changes that arise from global warming (e.g., Barange et al. 2018). One estimate suggests that by the 2050s there may be as much as a $21 \%$ drop in annual landed value, fisheriesrelated jobs may be reduced by $50 \%$, and costs to West Africa's economy might be as much as US\$311 million (Lam et al. 2012). Ghana, like much of the region, is set to see climate change impact both fish stocks and behaviors, already considered to be a key part of the decline of the Ghanaian fishing industry (Atindana et al. 2019). It has been suggested that the socioeconomic impacts of these changes to catch levels and species composition will have effects similar to those experienced as a result of the overexploitation of fishing stocks, pushing both industrial and artisanal fishers in the region to expand their fishing grounds, driving up operational costs (Belhabib et al. 2016).

\section{GHANA'S COASTAL COMMODITY FRONTIER}

The earliest signs of the global commodity markets on Ghana's coast are the castles and forts set up strategically as part of the trade of the various commodities extracted from the nation by settlers and colonists, including the many men, women, and children sold as slaves to work on early commodity frontiers in the Americas. More recently, there are two key coastal commodity frontiers in Ghana: the energy industry and fisheries. A drive to address the country's power shortages (at times severe) coupled with the discovery of commercial quantities of off-shore oil in 2007, has seen the construction of energy infrastructure across Ghana's coasts, especially its Western Region. Empirical research on Ghana's energy expansion has identified social and ecological disruptions for coastal fishing communities (Boohene and Peprah 2011, Nolan et al. 2019), indicating that the frontier thesis proposed by Moore rings true in this case.

The fisheries commodity frontier expanded to West Africa as a number of developed nations (including some from Western Europe, Russia, South Korea, and China) sought to expand the geographical extent of their operations following the depletion of fish in their own waters, starting in the 1950s and continuing to this day (Campling 2012). This is a process referred to by Moore (2010) as commodity widening, i.e., in which capitalist actors seek to appropriate ecological surplus by finding new uncommodified sites and expanding outward to the frontiers. This is as opposed to commodity deepening, in which actors seek surplus through technological or socioeconomic innovations to allow them to continue extracting surplus from existing frontiers. A permissive regulatory environment, coupled with a limited capacity for monitoring, controlling, and surveillance on Ghanaian waters has led to the over-exploitation of the country's fisheries, leaving fish stocks on the brink of collapse (EJF 2018).

\section{RESEARCH METHODOLOGY AND THE CASE OF ABOADZE, GHANA}

Research was conducted in Aboadze, a peri-urban SSMF community in the Western Region of Ghana's Shama district. It is approximately $200 \mathrm{~km}$ west of Ghana's capital Accra, and 20 km north-east of Ghana's third city Takoradi (known as "oil city" due to its importance to the country's nascent offshore oil industry). Aboadze is best known for hosting the Takoradi Thermal Power Station, which has been operating in the community since 1997 and run primarily by the state-owned Volta Rivers Authority (VRA) alongside several international private organizations. It was selected as a case study because it provides an illustrative case of interwoven stressors upon SSMF through land-based capital (power station), marine-based capital (industrial fishing), and vulnerability to climate change, which is characteristic of many coastal communities in West Africa (USAID 2018).

According to the most recent census in 2010, Aboadze's population was 9471; however, anecdotally, locally many feel this is now considerably higher. The vast majority of the community is ethnic Fante, with Christianity and Islam being the predominant religions. Aboadze is in many ways typical of a SSMF community in Ghana, and West Africa more broadly, because it is characterized by high levels of poverty, a lack of basic infrastructures such as clean running water, political and economic marginalization, and a heavy community reliance on fish as both a means of income and nutrition (Mills et al. 2011).

Aboadze is considered one of the major fishing communities of the Shama district (Coastal Resource Center 2013a), with the 
majority of its inhabitants deriving a livelihood from either the capture, processing, or trade of fish. Fishing is undertaken exclusively by men and boys in wooden canoes of varying sizes ranging from small vessels that carry 2 or 3 people, to large canoes that are capable of holding around 20. Most of the canoes use outboard motors to travel further and faster, and use a range of fishing gear including purse seine nets, set nets, and drifting gill nets to target primarily small-pelagic species, which make up $70 \%$ of Ghana's marine capture (FAO 2016). Women in the community are mainly tasked with the processing and trade of fish. Fish are smoked on wood burning clay stoves to preserve them and then sold either locally or at larger market hubs in the West Region and further afield. Farming in the community is rare, with a handful of small plots found across the town where staple foods such as cassava, tomatoes, and chillies are grown.

Our research drew primarily upon a mix of ethnographic methods, including interviewing, informal conversations, and participant observation. Ethnographies are capable of providing understandings of how global phenomena such as climate change play out on the ground (Malm and Esmailian 2013). In the case of double exposure research, "qualitative, ethnographic and visual methods will lead to rich narratives and historical accounts of local experiences of the interactions between stressors" (Bennett et al. 2016:918).

Additional research supplemented the ethnographic methods, including analysis of various relevant documents including environmental impact assessments from the nearby power station, government documentation, and civil society reports related to fishing and economic development, reflecting research locally and in the broader region. Data were also provided by the Ghana Statistical Service (2014) for demographic and census information, and climatic data were provided by the Ghana Meteorological Service.

Data were collected during an eight-month research visit to Ghana between November 2017 and July 2018. Prior to conducting interviews, a series of transect walks were undertaken to understand the logistics of the community and identify key infrastructures. From these, the town was divided into four areas (fishing area, seafront east, seafront west, and rear side). Each of the sections had defining features: for example, the fishing area was characterized by densely populated, poor quality housing, whereas the rear side was somewhat more sparsely populated, with larger and better constructed housing. When conducting community-level interviews, candidates were chosen from each of the four areas to ensure a diverse cross-section of participants.

Initially, 30 structured interviews were conducted (11 men and 19 women) to ascertain some of the key issues being faced in the community and other general scoping information. Following this, semi-structured interviews were conducted with community members (48 men, 41 women). Opportunistic (for the structured interviews) and purposeful sampling (for the semi-structured interviews) were used. For the semi-structured interviews, community members were primarily sought who make, or previously made, their living from the fishing industry. Additional interviews were conducted with local elites: the chief, chief fisherman, and assemblyman, staff from local institutions such as healthcare centres, the power station, schools, and also regional and national members of the Ghanaian government. Interviews sought information on living conditions in the region, the impacts of the various stressors on peoples' lives, and how they have had to change their behaviors accordingly.

The vast majority of community-level interviews were conducted through an interpreter in Fante, recorded digitally, and transcribed verbatim where possible, alongside the interpreter. The remaining interviews were conducted in English and then similarly transcribed. The resulting data were thematically analyzed, first categorized in relation to the three key stressors that are under investigation (climate, power station, and industrial fishing), before revealing points at which the stressors and the resulting impacts on livelihood would overlap.

\section{FINDINGS: PATHWAYS OF DOUBLE EXPOSURE IN A COASTAL COMMODITY FRONTIER}

The findings of the research are organized by the three pathways of double exposure: outcome, context, and feedback. A summary of the findings can be found in Table 1 .

\section{Outcome double exposure}

Outcome double exposure refers to the overlapping impacts of climate change and coastal capitalist commodity frontier expansion both in the form of industrial overfishing and coastal development. Three key areas of overlap were identified: access to food, to finances, and to water.

Although the presence of foreign fleets in Ghanaian waters has generated income for the national government through licence fees, the ensuing overfishing has driven the fish stocks to catastrophic lows in Ghana's coastal regions. It is thought as much as $90 \%$ of the industrial fishing fleet in Ghana is ultimately Chinese owned, despite Ghanaian law forbidding foreign ownership of vessels (EJF 2018). Vessel operators exploit a loophole in Ghanaian law by having a local front company and flying the flag of Ghana despite the fact that the ultimate beneficiaries of the fishing operations are primarily Chinese. This is symptomatic of an increasingly large Chinese presence in West Africa as the country seeks to meet growing domestic demand for fish and depleted national waters. There have been widespread reports of confirmed and suspected illegal, unreported, and unregulated (IUU) fishing among Chinese flagged and owned vessels, particularly in West Africa where monitoring, control, and surveillance efforts are hindered by a lack of capacity and corruption (EJF 2018, Greenpeace 2018, Gutiérrez et al. 2020).

There has also been a concurrent increase in the "saiko" trade, in which primarily Chinese-owned trawlers target locally consumed and traded fish and sell them to specially adapted canoes, which pits industrial fleets in direct competition for catch with canoe fishermen (EJF 2018). The resulting reduction in catch, and the changing nature of the catch, i.e., it has become increasingly common for juvenile fish to be caught and sold illegally when previously they would be thrown back (The deliberate capture of juvenile fish is illegal as per the Ghanaian Fisheries Act 2002), has seen a drastic downturn in food security in the community.

One frustrated community member stressed the issue of food security among fishers:

We have some people who are government workers and when the month ends they will go for their money, but for fishermen when the month ends they can't go for any 
Table 1. Summary of the findings.

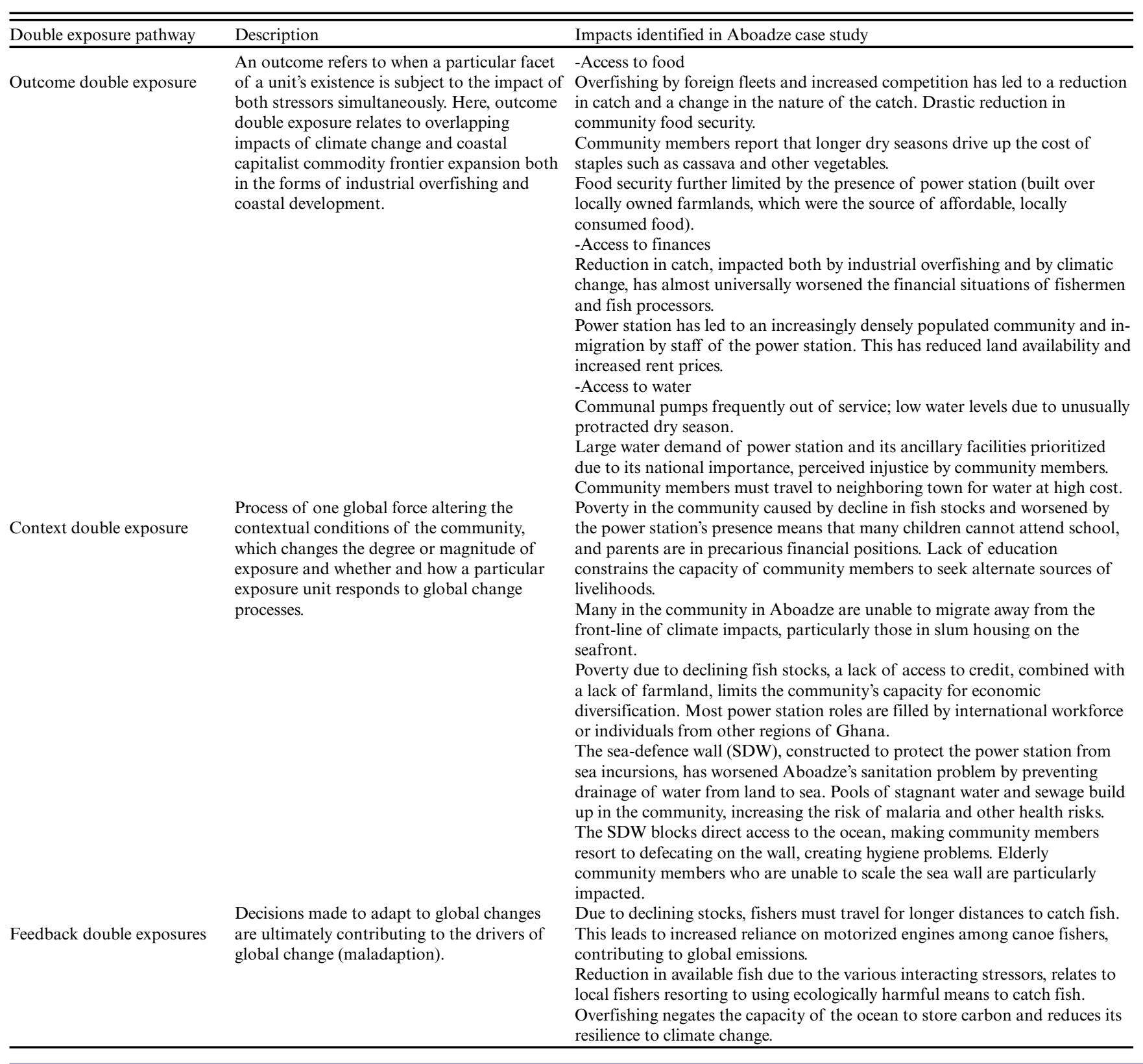

salary, so if we don't catch fish from the sea how can we get money to purchase food to eat? You see?

A local fisherman similarly voiced his concern for local people and anger, particularly at the perceived complicity of the Ghanaian Fishing Authorities for allowing foreign vessels to operate in Ghanaian waters:

All I can say is there is not enough fish stock for us. It is you the foreigners who have bought our people, you can sign so many licences for so many fishing trawlers, engage them in our waters and they are taking their salaries and everything! The common fisherman on our beach isn't taking anything, they haven't even taken porridge, but the politician has gone for his or her breakfast at the parliament - huge fried eggs and tea and we are sitting just by the sea and we are angry and we can't get a lot to eat.

Concurrently, changing climatic conditions appears to have impacted food security in the community. Members of the community felt that the temperature had warmed, and precipitation had reduced over the years. Rising sea temperatures are posing a serious issue in West Africa, as fish stocks are migrating away from their traditional habitats toward cooler climes (Oremus et al. 2020). One study suggests that since 1995, West Africa sardinella may be on average 200 miles further north 
than historically (Sarré et al. 2017). An elder member of the community stated:

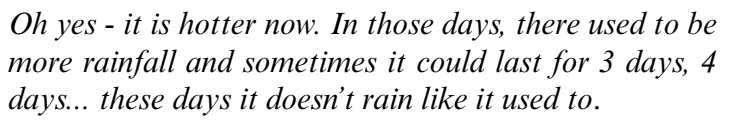

Oh yes - it is hotter now. In those days, there used to be more rainfall and sometimes it could last for 3 days, 4 days... these days it doesn't rain like it used to.

Such observations by community members are supported elsewhere in research findings. A 2018 study of spatiotemporal variations of rainfall and temperature found that Ghana has become progressively drier and drought prone in the last century, with the Western Region identified as a particularly critical area (Abbam et al. 2018). Changing weather patterns have allegedly driven the prices of local staple foods up. In particular, community members have complained that longer dry seasons drive up the cost of foodstuffs such as cassava and other vegetables, which form integral parts of their diets. One female member of the community said the following:

Prices are very high. If it is dry season the price is much higher. Dry season is expensive, when it starts raining the prices go down a little bit.

The ability of people in Aboadze to access affordable staple foods is further limited by the presence and the expansion of the power station, which was built over locally owned farmlands that were the source of affordable and locally consumed produce. An environmental impact assessment conducted on behalf of Amandi Energy Limited acknowledges that farmland was to be displaced as part of the construction of the power station, noting that "The project affected people (PAP) include owners/farmers of the crops within the proposed site boundary, together with owners of unused infrastructure found within the site" (Amandi Energy 2015:200). When asked why there are very few farms in Aboadze, one member of the community said the following:

For the elderly, feeding has become difficult because the VRA has come to buy the land they don't have anywhere to farm.

A male community member similarly reflected on the benefits of having farmlands and other food sources where the plant now stands:

The old men then had farms - they could come home with
palm nuts, firewood, and then there was a lagoon where
we could get seafood like tilapia, periwinkle, catfish, and
now due to the companies [referring to the power station]
they are no more. Even me, when I was hungry then I
could go there for a coconut and now I don't get coconut
to drink. Even then, when we didn't have water we could
go there for water when the plant was not there and now
the lagoon is spoiled.

Access to finance is the second key overlap of climate change and frontier expansion in this community. In Ghana, $80 \%$ of those involved in small-scale fisheries are considered to lie below the international poverty line of US\$2 per day (Asiedu et al. 2013). Access to financial assets plays a central role in limiting sensitivity to climatic change in fishing communities (Lancker et al. 2019). The reduction in catch experienced by community members, impacted both by industrial overfishing and climatic change, has almost universally worsened the financial situations of fishing communities. One fisherman highlighted the precarious financial situation he was in, essentially implying that he could not afford to fall ill:

$$
\begin{aligned}
& \text { In terms of money, it is not good at all. When we fall sick } \\
& \text { we don't have money to cater for ourselves. }
\end{aligned}
$$

A female member of the community who operated as a trader similarly described the hardships that arise from the lack of fish:

Now that my husband is not working, all the responsibility
is on me, so I have to carry things on my head and go and
sell to fend for the family. Also, at times I will have to
carry my child on my back to do the selling, because if
you don't do this there will be no money for the house
because the man is not working.

The power station has further exacerbated this issue, primarily through the premium that it has placed on land in Aboadze. According to an environmental and social review undertaken on behalf of the VRA (VRA 2009), the land use of the power station is approximately 168 hectares. Community members have complained of an increasingly densely populated community both as a result of the large swathes of land that were sold off to the power company, and due to the in-migration by staff of the power station, which has driven land availability down and rent prices up.

Access to drinking water provides another nexus in which climate and both sea and land-based capitalist frontier expansion interact. In Ghana, 20\% of the population is thought to lack access to safe drinking water (USAID 2019), and many inland water sources are contaminated due to illegal mining operations, locally known as "Galamsey" (Yeleliere et al. 2018). A prominent community complaint is that access to water in the community is sporadic, with the few communal pumps that exist being frequently out of service. Recent media reports suggest that the cuts in water supply were linked to damaged pipework during the construction of a nearby ceramic producer who has recently paid a "waiver" of 65,946 Ghanaian cedis toward pipe repairs (Atlantic Federation of African Press Agencies 2021). Climate has certainly played a part in this, with staff from the nearby Inchaban water treatment facility commenting that water levels were considerably lower than usual due to an unusually protracted dry season. This issue is ongoing, with the Ghana News Agency (Danquah 2020) reporting that water in the Sekondi-Takoradi metropolis was rationed in September 2020 due to low rainfall and increased demand.

Beyond the climatic drivers of reduced access to water, the introduction of the power station and its ancillary facilities comes with a huge demand for water, which is prioritized due to the national importance of the power station. Given the frequency of water shortages, community members (especially women and children) often find themselves having to travel to nearby Inchaban for water access. This comes at a considerably higher cost than if water was obtained locally. Community members often need to pay for a taxi, especially to transport the water back, exacerbating the declining incomes experienced in the face of overfishing. Members of the community feel particularly aggrieved due to the difficulties accessing water, which is made even less bearable by the fact that the power station and its attached accommodation has a constant supply of water. One member of the community said: 


\begin{abstract}
With water we are suffering, yet if you come to the VRA township people have water 24/7 - I feel it's a cheat.
\end{abstract}

\section{Context double exposure}

Context double exposure refers to the process of one global force altering the contextual conditions of the community, which changes the "degree or magnitude of exposure and whether and how a particular exposure unit responds to global change processes" (Leichenko and O'Brien 2008:35). The following findings outline how contextual changes have shaped the capacity of community members to adapt to their changing environments, ultimately condemning many to more severe negative effects.

In interviews with community schoolteachers, it was clear that poverty in the community meant that many children could not attend school. This was reportedly due to parents not being able to afford things like uniforms and books, even in schools with no fees. One member of the community told the researcher how she had just returned from her children's school to discuss finances:

As I am talking to you I have just come from the school and they said I had to pay 300 cedis [equivalent to approximately US\$50], so I went there to plead with them so that they will not sack my children because myself I don't have any money on me.

Non-governmental organization Friends of the Nation reported in a 2010 report that enrolment in schools in Aboadze was very low, linked to a lack of incentives such as free school uniforms. More than one teacher said that quite often children would come to school but leave to make money at the seafront to feed themselves. One teacher discussed the impact of poverty on parental engagement:

They [parents] are struggling to get money, so they feel like those hours in the day [attending meetings with the school] are a waste of time, when they could be going to get money. As I said, parental care is a very key challenge here, they can't really think about the ones they have brought to the school, they are always thinking about how to survive, how to get money.

A staff member at one school that had a funded lunch program, remarked on the considerable difference it made on attendance, which drives home the precarity in which many in Aboadze find themselves living. Although the power station has built a school in the town, it primarily serves members of staff and other wealthier locals, with its fees being considerably higher than what most fishing families are able to pay (closer analysis of such initiatives by the power station can be found in Nolan et al. 2019).

A recent World Bank study suggests that in West Africa, a region disproportionately impacted by coastal erosion, tens of thousands of people a year are likely dying due to flooding and changes in air and water quality (Croitoru et al. 2019). In Ghana, estimates suggest that coastal erosion is occurring at a rate of two metres per year with dire consequences for coastal communities (Evadzi et al. 2017). The ability to migrate away from the front line of climate impacts can also be considered a facet of adaptive capacity. Here again, we see how capitalist expansion limits the ability of the community in Aboadze, which is faced with rising sea levels, by both reducing their financial power and limiting mobility: the massive land demands of the power station, coupled with an influx of in-migration to the region means that very little land is now available locally. The members of the community who are most likely to be impacted by sea-level rise are those in inadequate housing closest to the sea front, which is both closest to the sea and the most poorly constructed. These are the people who are the most impacted by egregious overfishing and as such have limited financial means. Thus, even if there was land available and/or if they were willing to leave the community, it is highly unlikely that they would be able to afford to do so.

Fishermen and fish processors in Aboadze, often with low levels of formal education and limited opportunities for alternative employment, are in most cases entirely reliant on the fishing industry as a source of income. Economic diversification is an important facet of adaptive capacity because it increases resilience to climate and other related stressors (Arslan et al. 2018, Lancker et al. 2019). However, the poverty induced by declining fish stocks coupled with the difficulty of many to access credit (Nolan 2019) means that investments required for enterprise or innovation are often unobtainable. Furthermore, because of the seasonal nature of farming and fishing, many in the community would often undertake both activities alternatively or in parallel to improve food and financial security. With the loss of farm and other available land in Aboadze, farming in the community is almost non-existent except for a few small patches of farmland, depriving many of the opportunity to diversify their sources of income. The presence of the power station has done little to counteract these changes through providing employment for locals, with only a small number of community members employed, primarily in low-paying jobs. The vast majority of available roles are filled by an international workforce or by more formally qualified individuals from other regions of Ghana.

Leichenko and O'Brien (2008:48) stressed that "changes in the contextual environment may also result from local responses and adaptations to processes of global change." In response to climate induced sea-level rise, a sea-defence wall (SDW) was constructed in 2016 by the Government of Ghana near the power station and extending westward toward the fish-landing site. This was done mainly to serve as protection for the power station as a national asset. Although a second phase of construction of SDW was planned to protect the low-lying, densely inhabited seafront, it has not yet materialized ostensibly due to a lack of funding. Even though community members recognized that the SDW had limited sea incursions into the area, its construction and the associated changes to the biophysical context of the community has created problems for people living in its direct vicinity, with one member of local government saying it "has brought in more harm than good". A report by local civil society group Hen Mpoano (Coastal Resources Center 2013b:2) listed Aboadze's SDW among several other similar structures that "did not adequately serve their intended function or have simply failed." Specifically, community members feel that the SDW has severely worsened an already dire sanitation problem, stopping the drainage of water traveling from land to sea, which leads to pools of stagnant water and sewage building up in the community. Stagnant water is not only unpleasant but attracts mosquitoes and as such will likely increase instances of malaria, a common local health complaint. In addition to death, malaria can create additional financial burdens for sufferers both in accessing healthcare and potentially having to miss work as a result of contraction. 
Furthermore, the lack of functioning toilets means that many members of the community must defecate in the ocean, but with the presence of the SDW now blocking direct access to the ocean many have resorted to defecating on the wall, creating hygiene problems. One member of the community highlighted this as a key problem facing the town:

\begin{abstract}
Anytime we went to toilet the sea will come and collect all of them away. Now that the fence [the SDW] is built they were supposed to pass gutters through them so that water from the community can pass and enter the sea but because of this [the lack of gutters] the waters stay in the community and dries up.
\end{abstract}

\section{Feedback double exposures}

Feedback double exposures show how actions taken in response to either, or both, forces of global change can contribute further to their drivers, thus perpetuating these drivers of vulnerability. We identified two sets of feedbacks in which decisions made to adapt to global changes are ultimately contributing to the drivers of global change.

First, members of the fishing community widely complained of having to travel farther and for longer distances to capture fish, leading to an increased reliance on motorized engines among the canoe fishers (Nolan 2019). This is a pattern that has been noticed for SSMF globally, linked to both overfishing and a changing climate (Monnier et al. 2020). The use of motorized engines on a global scale can stand to make a significant contribution to global emissions, thereby worsening the impacts of global climate change.

A second identifiable feedback, again in reaction to a reduction in available fish due to the various interacting stressors, relates to local fishers resorting the use of ecologically harmful means to catch fish. Examples of this include the use of undersized monofilament nets, light fishing in which a light is lowered into the water to act as a fish-aggregating device, dynamite fishing, and poison fishing. These practices are recognized as occurring across Ghana more broadly (Afoakwah et al, 2018). Increasingly, we are becoming aware of the value of blue carbon, i.e., the carbon that is stored within coastal and marine ecosystems. Overfishing continues to negate the capacity of the ocean to store carbon and simultaneously reduces its resilience to the changing climate (Sumaila and Tai 2019). Therefore, the maladaptive behavior of using harmful methods to counteract frontier and climateinduced fish stock changes will ultimately create a feedback loop and worsen the severity of climatic change.

\section{DISCUSSIONS AND CONCLUSIONS: UNDERSTANDING DOUBLE EXPOSURE IN MARGINALIZED COASTAL COMMUNITIES}

The above depictions of life on the coastal commodity frontier paint vivid images of the social-ecological upheaval that lies in the wake of capitalism's inherent need to expand, creating poverty, insecurity, and suffering among some of the world's most vulnerable people. Parallel to this, when we read of regions impacted by climate change, similar pictures of precarity and human suffering emerge. The similarities and linkages between these two phenomena however have been largely unexplored. However, even at an initial glance, their combined impacts are clear. Both climate change and coastal capitalist commodity frontier expansion manifest most intensively among rural communities in less economically developed countries, both have higher impacts upon the poor, upon women, upon the elderly, and upon those whose capacity to cope has been hindered through historical and structural inequalities. The benefits and burdens of the commodity frontier and climate change are unfairly distributed: those who bear the brunt of these phenomena are those who gain the least, whereas those who reap the benefits are often temporally and spatially removed from immediate consequences. Finally, and importantly, the actors responsible for these global catastrophes are ultimately the same relatively small group of powerful multinational corporations that mobilize vast amounts of political influence and financial might to maintain the status quo at great cost to human and non-human nature alike, in the ongoing quest for financial gains.

Maybe surprisingly, given both the theoretical and geographical proximity of these two issues and their externalities, there has been a lack of work that considers how the vulnerabilities that arise in frontier spaces interact with those that arise from climatic change. We have addressed this gap by using a novel framework informed by the double exposure framework, which seeks to look at the dynamic entanglements between climate change and other stressors and how the manifestations and feedbacks of these create specific forms of vulnerability. Analyzed through the three pathways of double exposure, i.e., outcome, context, and feedback, this framework provides an overview of the obvious and more subtle ways in which these two global processes manifest in a particular space.

Our study has explored the above interactions in the specific context of the coastal commodity frontier, through documenting impacts on a small-scale marine fishing community in Ghana. In so doing, it is argued that the coastal frontier is unique in that it can experience parallel processes of expansion, both at sea and on land. This particular empirical example looks at the interactions between industrial fishing, a thermal power station, and the climatic impacts occurring in coastal Ghana. Understanding the specific interactions among these three is important because of the increasing use of power stations on the continent, the fact they are often placed in close proximity to the oceans, and the fact that coastal regions in sub-Saharan Africa are considered some of the most climate-vulnerable regions in the world.

In Aboadze, climate change, coastal development, and overfishing intertwine in a number of ways, with severe implications for members of the community. The findings have shown that the direct outcomes of frontier expansion and climate change interact across critical intersections of food security, poverty, and access to water, worsening these for the majority of the community. The contextual changes that arise from these dual global processes have by and large reduced the capacity of community members to adapt to their worsening conditions. Poverty, caused in large part by overfishing, has created a barrier to educating children in the community, with parents simply unable to afford to send their children to school, and children having to leave school to earn enough money for lunch. A lack of education constrains the capacity of community members to seek alternate sources of livelihoods, an integral facet of adaptive capacity. Similarly, this poverty, coupled with an increase in land 
demand linked to the arrival of the power station has meant that those most sensitive to sea-level rise are unable to move away from the seafront and as such are at risk of losing their houses and their livelihoods. Findings have also suggested that changes have arisen from responses and adaptations to the processes of global change, in particular that the construction of the SDW to protect against rising sea levels has in fact failed to fully protect the community, unintentionally creating further sanitation problems. Finally, our framing has identified feedbacks that may result from adaptions and maladaptations to global processes, with fishers forced to take longer and more carbon intensive trips at sea, and to use harmful methods to capture fish, which undermine the blue carbon capacity of the ocean, thereby contributing to the perpetuation of climate-induced changes.

An important facet of the double exposure framework is that it brings to the forefront the ideas of winners and losers in global change and recognizes that there are "double winners" and "double losers," i.e., those that are positively or negatively impacted by both climate change and other economic global changes. This focus makes apparent the stark distributional injustices that occur across scales. Through this broader lens, the vast majority of community members appear to be double losers insofar as they are negatively impacted by both global changes due to their heavy reliance on natural resources for livelihood and food security, whereas the double winners would be those large multinational companies who both profit from exploiting the same natural resources and reaping the benefits of their heavy emissions while doing so. At a community level, we also see a differentiation in who is impacted and to what extent, often determined by class and gender. For example, middle-class members of the local area are able to take advantage of power station accommodation with its constant running water and electricity, as well as the international school, which requires fees to be paid. However, poorer community members, in particular women and children, are forced to travel farther and pay more for water due to double exposures. Likewise, poorer members of the community who live in shanty housing at the seafront will be impacted most by sea-level rise, as opposed to the slightly wealthier who live further inland.

We have sought to galvanize a theoretical and empirical conversation between capitalist frontier expansion and climate change, two phenomena that are inherently linked in both cause and effect. Doing so has strong implications for both grounded pursuits such as vulnerability analyses and theoretical questions of justice and responsibility. It is meant to serve an exploratory purpose, i.e., an initial delving into some of the ways that configurations of climate change and capitalist expansion impact communities and specifically in this case, coastal communities and the theoretical tools we can use to analyze them. Such an approach is somewhat limited in the level of detail afforded to these complex interactions, all of which warrant considerably deeper investigation into the intersection between food insecurity, poverty, and water scarcity. Further research would be well placed to look at these intersections, considering in greater detail how local factors such as culture, religion, norms, and institutions also interact with global stressors to sculpt and/or resist vulnerability. The key takeaway is, however, that the key stressors upon SSMF communities in the forms of climate change, overfishing, and coastal development must be considered in the context of one another to provide better and more accurate accounts of vulnerability and as such can inform relevant policy and interventions by civil society.

Responses to this article can be read online at: https://www.ecologyandsociety.org/issues/responses. php/12815

\section{Acknowledgments:}

The authors thank the editor and the reviewers for their feedback and suggestions for improving this paper; all errors or exclusions remain the responsibility of the authors. They would also thank the research partners who were so integral to this work, and most importantly the community in Aboadze for their cooperation and endless warmth.

\section{Data Availability:}

The data that support the findings of this study are available on request from the corresponding author, $C N$. None of the data are publicly available because they contain information that could compromise the privacy of research participants. Ethical approval for this research study was granted by the University of Reading Research Ethics Committee.

\section{LITERATURE CITED}

Abbam, T., F. A. Johnson, J. Dash, and S. S. Padmadas. 2018. Spatiotemporal variation in rainfall and temperature in Ghana over the twentieth century, 1900-2014. Earth and Space Science 5(4):120-132. https://doi.org/10.1002/2017EA000327

Afoakwah, R., M. Osei, D. Bonsu, and E. Effah. 2018. A guide on illegal fishing activities in Ghana. USAID/Ghana Sustainable Fisheries Management Project. Coastal Resources Center, Graduate School of Oceanography, University of Rhode Island, Narragansett, Rhode Island, USA. [online] URL: https://www. crc.uri.edu/download/GH2014_SCI048_UCC FIN508.pdf

Allison, E. H., A. L. Perry, M.-C. Badjeck, W. N. Adger, K. Brown, D. Conway, A. S. Halls, G. M. Pilling, J. D. Reynolds, N. L. Andrew, and N. K. Dulvy. 2009. Vulnerability of national economies to the impacts of climate change on fisheries. Fish and Fisheries 10(2):173-196. https://doi.org/10.1111/j.1467-2979.2008.00310. $\underline{x}$

Amandi Energy. 2015. Updated environmental and social impact assessment. $190 \mathrm{MW}$ combined cycle power plant at Aboadze, Ghana. Amandi Energy Limited, London, UK. [online] URL: https://www.miga.org/sites/default/files/archive/Documents/ESIAAmandi-Energy-Independent-Power-Plant-May-2015.pdf

Arslan, A., R. Cavatassi, F. Alfani, N. Mccarthy, L. Lipper, and M. Kokwe. 2018. Diversification under climate variability as part of a CSA strategy in rural Zambia. Journal of Development Studies 54(3):457-480. https://doi.org/10.1080/00220388.2017.1293813 
Asiedu, B., F. K. E. Nunoo, P. K. Ofori-Danson, D. B. Sarpong, and U. R. Sumaila. 2013. Poverty measurements in small-scale fisheries of Ghana: a step towards poverty eradication. Current Research Journal of Social Sciences 5(3):75-90. https://doi. org/10.19026/crjss.5.5542

Atindana, S. A., P. K. Ofori-Danson, and S. Brucet. 2019. Modelling the effects of climate change on shellfish production in marine artisanal fisheries of Ghana. Climate 2(16):1-14. https:// doi.org/10.12688/aasopenres. 12956.1

Atlantic Federation of African Press Agencies. 2021. Twyford and GWCL make moves to resolve Aboadze, Abuesi water crisis. Atlantic Federation of African Press Agencies, Rabat, Morocco. [online] URL: http://www.faapa.info/blog/twyford-and-gwclmake-moves-to-resolve-aboadze-abuesi-water-crisis/

Atta-Mills, J., J. Alder, and U. R. Sumaila. 2004. The decline of a regional fishing nation: the case of Ghana and West Africa. Natural Resources Forum 28:13-21. https://doi.org/10.1111/ j.0165-0203.2004.00068.x

Barange, M., T. Bahri, M. C. M Beveridge, K. L. Cochrane, S. Funge-Smith, and F. Poulain. 2018. Impacts of climate change on fisheries and aquaculture: synthesis of current knowledge, adaptation and mitigation options. FAO Fisheries and Aquaculture Technical Paper No. 627. FAO, Rome, Italy. [online] URL: https://www.fao.org/3/i9705en/I9705EN.pdf

Barbesgaard, M. 2018. Blue growth: savior or ocean-grabbing? Journal of Peasant Studies 45(1):130-149. https://doi. org/10.1080/03066150.2017.1377186

Bavinck, M., F. Berkes, A. Charles, A. C. E. Dias, N. Doubleday, P. Nayak, and M. Sowman. 2017. The impact of coastal grabbing on community conservation - a global reconnaissance. Maritime Studies. 16(8):8(2017). https://doi.org/10.1186/s40152-017-0062-8

Bebbington, A. J., J. Bury, N. Cuba, and J. Rogan. 2015. Mining, risk and climate resilience in the "other" Pacific: Latin American lessons for the South Pacific. Asia Pacific Viewpoint 56 (2):189-207. https://doi.org/10.1111/apv.12098

Belhabib, D., V. W. Y. Lam, and W. W. L Cheung. 2016. Overview of West African fisheries under climate change: impacts, vulnerabilities and adaptive responses of the artisanal and industrial sectors. Marine Policy 71:15-28. https://doi. org/10.1016/j.marpol.2016.05.009

Benjaminsen, T. A., and I. Bryceson. 2012. Conservation, green/ blue grabbing and accumulation by dispossession in Tanzania. Journal of Peasant Studies 39(2):335-355. https://doi. org/10.1080/03066150.2012.667405

Bennett, N. J., J. Blythe, S. Tyler, and N. C. Ban. 2016. Communities and change in the anthropocene: understanding social-ecological vulnerability and planning adaptations to multiple interacting exposures. Regional Environmental Change 16(4):907-926. https://doi.org/10.1007/s10113-015-0839-5

Bennett, N. J., H. Govan, and T. Satterfield. 2015. Ocean grabbing. Marine Policy 57:61-68. https://doi.org/10.1016/j. marpol.2015.03.026

Boohene, R., and J. Peprah. 2011. Women, livelihood and oil and gas discovery in Ghana: an exploratory study of of Cape Three
Points and surrounding communities. Journal of Sustainable Development 4(3):185-195. https://doi.org/10.5539/jsd.v4n3p185

Campling, L. 2012. The Tuna 'commodity frontier': business strategies and environment in the industrial tuna fisheries of the Western Indian Ocean. Journal of Agrarian Change 12 (2-3):252-278. https://doi.org/10.1111/j.1471-0366.2011.00354.X

Coastal Resources Center. 2013a. Shama District integrated coastal management toolkit. Integrated coastal and fisheries governance initiative (Hzn Mpoano). Coastal Resources Center at the Graduate School of Oceanography, University of Rhode Island, Narragansett, Rhode Island, USA. [online] URL: https:// www.crc.uri.edu/download/GH2009DS002 Shama S 508.pdf

Coastal Resources Center. 2013b. Coastal hazards and flooding risk in Ghana's Western Region. Issue Brief 7 in series "Hzn Mpoano: our coast, our future." Coastal Resources Center, Graduate School of Oceanography, University of Rhode Island. Narragansett, Rhode Island, USA. [online] URL: https://www. crc.uri.edu/download/GH2009COM009ib7 shore 508.pdf

Crain, C. M., K. Kroeker, and B. S. Halpern. 2008. Interactive and cumulative effects of multiple human stressors in marine systems. Ecology Letters 11(12):1304-1315. https://doi. org/10.1111/j.1461-0248.2008.01253.X

Croitoru, L., J. J. Miranda, and M. Sarraf. 2019. The cost of coastal zone degradation in West Africa: Benin, Cote D'Ivoire, Senegal and Togo. World Bank, Washington, D.C., USA. [online] URL: https://documents1.worldbank.org/curated/en/822421552504665834/ pdf/The-Cost-of-Coastal-Zone-Degradation-in-West-Africa-BeninCote-dIvoire-Senegal-and-Togo.pdf

Crona, B., T. Van Holt, M. Petersson, T. M. Daw, and E. Buchary. 2015. Using social-ecological syndromes to understand impacts of international seafood trade on small-scale fisheries. Global Environmental Change 35:162-175. https://doi.org/10.1016/j. gloenvcha.2015.07.006

Danquah, S. 2020. GWCL rations water in Sekondi-Takoradi and its environs. Ghana News Agency. 30 September. [online] URL: https://www.gna.org.gh/1.18840796

Daw, T., W. N. Adger, K. Brown, and M.-C. Badjeck. 2009. Climate change and capture fisheries: potential impacts, adaptation and mitigation. Pages 107-150 in K. Cochrane, C. De Young, D. Soto and T. Bahri, editors. Climate change implications for fisheries and aquaculture: overview of current scientific knowledge. FAO Fisheries and Aquaculture Technical Paper. No. 530. FAO, Rome, Italy. [online] URL: https://digitalarchive. worldfishcenter.org/bitstream/handle/20.500.12348/1339/WF 2545. pdf? sequence $=1$

Environmental Justice Foundation (EJF). 2018. China's hidden fleet in West Africa: a spotlight on illegal practices within Ghana's industrial trawl sector. Environmental Justice Foundation, London, UK. [online] URL: https://ejfoundation.org/reports/ chinas-hidden-fleet-in-west-africa-a-spotlight-on-illegal-practiceswithin-ghanas-industrial-trawl-sector

Ertör, I., and M. Ortega-Cerda. 2019. The expansion of intensive marine aquaculture in Turkey: the next to last commodity frontier? Journal of Agrarian Change 19(2):337-360. https://doi. org/10.1111/joac. 12283 
Evadzi, P. I. K., E. Zorita, and B. Hünicke. 2017. Journal of Coastal Research 33(6):1283-1291. https://doi.org/10.2112/ JCOASTRES-D-16-00119.1

Fabinyi, M., W. Dressler, and M. Pido. 2018. Access to fisheries in the maritime frontier of Palawan Province, Philippines. Singapore Journal of Tropical Geography 40:92-110. https://doi. org/10.1111/sjtg. 12260

Food and Agriculture Organization of the United Nations (FAO). 2016. Fisheries and aquaculture country profiles, Republic of Ghana. FAO, Rome, Italy. [online] URL: https://www.fao.org/ fishery/en/facp/gha?lang=en

Food and agriculture Organization of the United Nations (FAO). 2020. The state of world fisheries and aquaculture 2020: sustainability in action. FAO, Rome, Italy. [online] URL: https:// www.fao.org/documents/card/en/c/ca9229en/

Freduah, G., P. Fidelman, and T. F. Smith. 2017. The impacts of environmental and socio-economic stressors on small scale fisheries and livelihoods of fishers in Ghana. Applied Geography 89:1-11. https://doi.org/10.1016/j.apgeog.2017.09.009

Freduah, G., P. Fidelman, and T. F. Smith. 2019. A framework for assessing adaptive capacity to multiple climatic and nonclimatic stressors in small-scale fisheries. Environmental Science and Policy 101(1):87-93. https://doi.org/10.1016/j.envsci.2019.07.016

Gaines, S. D., C. Costello, B. Owashi, T. Mangin, J. Bone, J. G. Molinos, M. Burden, H. Dennis, B. S. Halpern, C. V. Kappel, K. M. Kleisner, and D. Ovando. 2018. Improved fisheries management could offset many negative effects of climate change. Science Advances 4(8):709. https://doi.org/10.1126/sciadv. $\underline{\text { aao } 1378}$

Ghana Statistical Service. 2014. 2010 population and housing census: district analytical report: Shama District. Ghana Statistical Service, Accra, Ghana. [online] URL: https://www2. statsghana.gov.gh/docfiles/2010 District Report/Western/Shama. pdf

Gilbert, D. E. 2018. Territorialization in a closing commodity frontier: the Yasuní rainforests of West Amazonia. Journal of Agrarian Change 18(2):229-248. https://doi.org/10.1111/joac.12227

Greenpeace. 2018. The cost of ocean destruction: report from Greenpeace ship tour of West African fisheries 2017. Greenpeace, London, UK. [online] URL: https://www.greenpeace.org/static/ planet4-africa-stateless/2018/10/154ab281-154ab281-the.cost .of . ocean .destruction.pdf

Gutiérrez, M., A. Daniels, G. Jobbins, G. G. Almazor, and C. Montenegro. 2020. China's distant-water fishing fleet: scale, impact and governance. Overseas Development Institute, London, UK. [online] URL: https://cdn.odi.org/media/ documents/chinesedistantwaterfishing web.pdf

International Panel on Climate Change (IPCC). 2014. Livelihoods and poverty. Pages 793-832 in Climate change 2014: impacts, adaptation, and vulnerability. Part A: global and sectoral aspects. Contribution of Working Group II to the Fifth Assessment Report of the Intergovernmental Panel on Climate Change. Cambridge University Press, Cambridge, UK. https:// doi.org/10.1017/CBO9781107415379.018
International Panel on Climate Change (IPCC). 2019. Summary for policymakers in H.-O. Pörtner, D. C. Roberts, V. MassonDelmotte, P. Zhai, M. Tignor, E. Poloczanska, K. Mintenbeck, A. Alegría, M. Nicolai, A. Okem, J. Petzold, B. Rama, and N. M. Weyer, editors. IPCC Special report on the ocean and cryosphere in a changing climate. Cambridge University Press, Cambridge, UK. [online] URL: https://www.ipcc.ch/site/assets/uploads/ sites/3/2019/11/03_SROCC_SPM_FINAL.pdf

Lam, V. W. Y., W. W. L. Cheung, W. Swartz, and U. R. Sumaila. 2012. Climate change impacts on fisheries in West Africa: implications for economic, food and nutritional security. African Journal of Marine Science 34(1):103-117. https://doi. org/10.2989/1814232X.2012.673294

Lancker, K., A.-L. Deppenmeier, T. Demissie, and J. O. Schmidt. 2019. Climate change adaptation and the role of fuel subsidies: an empirical bio-economic modeling study for an artisanal openaccess fishery. PLoS ONE 14(8):e0220433. https://doi. org/10.1371/journal.pone.0220433

Leichenko, R. M., and K. L. O'Brien. 2002. The dynamics of rural vulnerability to global change: the case of Southern Africa. Mitigation and Adaptation Strategies for Global Change 7:1-18. https://doi.org/10.1023/A:1015860421954

Leichenko, R. M., K. L. O'Brien. 2008. Environmental change and globalization: double exposures. Oxford University Press, Oxford, UK.

Lennox, E. 2015. Double exposure to climate change and globalization in a Peruvian Highland Community. Society and Natural Resources 28(7):781-796. https://doi.org/10.1080/08941$\underline{920.2015 .1024364}$

Malm, A. and S. Esmailian. 2013. Ways in and out of vulnerability to climate change: abandoning the Mubarak Project in the Northern Nile Delta, Egypt. Antipode 45(2):474-492. https://doi. org/10.1111/j.1467-8330.2012.01007.x

Marley, B. J. 2016. The coal crisis in Appalachia: agrarian transformation, commodity frontiers and the geographies of capital. Journal of Agrarian Change 16(2):225-254. https://doi. org/10.1111/joac.12104

Meerow, S. 2017. Double exposure, infrastructure planning, and urban climate resilience in coastal megacities: a case study of Manila. Environment and Planning A 49:2649-2672. https://doi. org/10.1177/0308518X17723630

Mills, D. J., L. Westlund, G. de Graaf, Y. Kura, R. Willman, and K. Kelleher. 2011. Under-reported and undervalued: small-scale fisheries in the developing world. Pages 1-15 in R. S. Pomeroy and N. L. Andrew, editors. Small-scale fisheries management: frameworks and approaches for the developing world. Cabi, London, UK. https://doi.org/10.1079/9781845936075.0001

Monnier, L., D. Gascuel, J. J. Alava, M. J. Barragán, N. Gaibor, F. A. Hollander, P. Kanstinger, S. Niedermueller, J. Ramírez, and W. W. L. Cheung. 2020. Small-scale fisheries in a warming ocean: exploring adaptation to climate change. Scientific report. WWF Germany, Berlin, Germany. [online] URL: https://www. fishforward.eu/wp-content/uploads/2020/09/WWF small-scale-fisheriesin-a-warming-ocean exploring-adaptation-to-climatechange FishForward_2020_EN_WEB.pdf 
Moore, J. W. 2000. Sugar and the expansion of the early modern world economy: commodity frontiers, ecological transformation, and industrialisation. Review 23(3):409-433.

Moore, J. W. 2010. Madeira, sugar, and the conquest of Nature in the "first" Sixteenth century, part II: from regional crisis to commodity frontier 1506-1530. Review (Fernand Braudel Center) 33(1):1-24. [online] URL: https://jasonwmoore.com/wp-content/ uploads/2017/08/Moore-Madeira-Part-II-2010-REVIEW.pdf

Moore, J. W. 2018. The Capitalocene part II: accumulation by appropriation and the centrality of unpaid work/energy. Journal of Peasant Studies 45(2):237-279. https://doi.org/10.1080/03066$\underline{150.2016 .1272587}$

Nolan, C., M. K. Goodman, and F. Menga. 2019. In the shadows of power: the infrastructural violence of thermal power generation in Ghana's coastal commodity frontier. Journal of Political Ecology 27(1):775-794. https://doi.org/10.2458/v27i1.23571

O’Brien, K. L., and R. M. Leichenko. 2000. Double exposure: assessing the impacts of climate change within the context of economic globalization. Global Environmental Change 10:221-232. https://doi.org/10.1016/S0959-3780(00)00021-2

Oremus, K. L., J. Bone, C. Costello, J. G. Molinos, A. Lee, T. Mangin, and J. Salzman. 2020. Nature Sustainability 3:277-280. https://doi.org/10.1038/s41893-020-0476-y

Otto, I. M, D. Reckien, C. P. O. Reyer, R. Marcus, V. Le Masson, L. Jones, A. Norton, and O. Serdeczny. 2017. Social vulnerability to climate change: a review of concepts and evidence. Regional Environmental Change 17(6):1651-1662. https://doi.org/10.1007/ s10113-017-1105-9

Saguin, K. 2016. Blue revolution in a commodity frontier: ecologies of aquaculture and agrarian change in Laguna Lake, Philippines. Journal of Agrarian Change 16(4):571-593. https:// doi.org/10.1111/joac. 12114

Sarré, A., H. Demarcq, S. Faye, P. Brehmer, J. O. Krakstad, D. Thiao, and S. Elayoubi. 2017. Climate-driven shift of Sardinella aurita stock in Northwest Africa ecosystem as evidenced by robust spatial indicators. In P. Brehmer, B. Ba, and G. Kraus, editors. International conference ICAWA 2016: extended book of abstract: the AWA project: ecosystem approach to the management of fisheries and the marine environment in West African waters, Dakar, Senegal. https://www.documentation.ird. fr/hor/fdi:010072122

Shackleton, S., and C. M. Shackleton. 2012. Linking poverty, HIV/AIDS and climate change to human and ecosystem vulnerability in southern Africa: consequences for livelihoods and sustainable ecosystem management. International Journal of Sustainable Development and World Ecology 19(3):275-286. https://doi.org/10.1080/13504509.2011.641039

Sih, A., A. M. Bell., and J. L. Kerby. 2004. Two stressors are far deadlier than one. Trends in Ecology and Evolution 19 (6):274-276. https://doi.org/10.1016/j.tree.2004.02.010

Sumaila, U. R., W. W. L. Cheung, V. W. Y. Lam, D. Pauly, and S. Herrick. 2011. Climate change impacts on the biophysics and economics of world fisheries. Nature Climate Change 1 (9):449-456. https://doi.org/10.1038/nclimate1301
Sumaila, U. R., and T. C. Tai. 2019. Ending overfishing can mitigate impacts of climate change. Institute for the Oceans and Fisheries Working Paper Series \#2019-5. Institute for the Oceans and Fisheries, University of British Columbia, Vancouver, British Columbia, Canada. [online] URL: https://fisheries.sites.olt.ubc. ca/files/2019/11/2019-05-Sumaila_Ending_overfishing.pdf

United States Agency International Development (USAID). 2018. Climate risk profile: West Africa. USAID, Washington, D. C., USA. [online] URL: https://reliefweb.int/sites/reliefweb.int/ files/resources/West Africa CRP Final.pdf

United States Agency International Development (USAID). 2019. Ghana water. USAID, Washington, D.C., USA. [online] URL: https://www.usaid.gov/ghana/water

Volta Rivers Authority (VRA). 2019. Takoradi thermal power plant expansion project (T3) environmental impact assessment. Volta Rivers Authority, Accra, Ghana. [online] URL: https:// www.miga.org/sites/default/files/archive/Documents/EIA Takoradi. pdf

Vinebrooke, R. D., K. L. Cottingham, J. Norberg, M. Scheffer, S. I. Dodson, S. C. Maberly, and U. Sommer. 2004. Impacts of multiple stressors on biodiversity and ecosystem functioning: the role of species co-tolerance. Oikos 104:451-457. https://doi. org/10.1111/j.0030-1299.2004.13255.x

Yeleliere, E., S. J. Cobbina, and A. B. Duwiejuah. 2018. Review of Ghana's water resources: the quality and management with particular focus on freshwater resources. Applied water science. 8:93(2018). https://doi.org/10.1007/s13201-018-0736-4

Zanna, L., S. Khatiwala, J. M. Gregory, J. Ison, and P. Heimbach. 2019. Global reconstruction of historical ocean heat storage and transport. Proceedings of the National Academy of Sciences 116 (4):1126-1131. https://doi.org/10.1073/pnas.1808838115 